\title{
Risk Analysis of the 1944 Treaty between the United States and Mexico for the Rio Grande/Bravo Basin
}

\author{
S. Sandoval-Solis ${ }^{1}$ and Daene C. McKinney ${ }^{2}$ \\ ${ }^{1}$ Center for Research in Water Resources, University of Texas at Austin, Austin, TX \\ 78712; PH (512) 471-0071; FAX (512) 471-0072; email: \\ samuel.sandovalsolis@gmail.com \\ ${ }^{2}$ Center for Research in Water Resources, University of Texas at Austin, Austin, TX \\ 78712; PH (512) 471-5644; FAX (512) 471-0072; email: daene@aol.com
}

\begin{abstract}
The treaty of 1944 between United States (U.S.) and Mexico defines the water allocation of both countries for the Colorado, Tijuana and Rio Grande/Bravo rivers. This paper focuses its attention in the treaty obligations of water delivery from Mexico to the US in the Rio Grande/Bravo basin. For this basin, the treaty specifies a primary division of six tributaries originating in Mexico as one-third to the U.S. and two-thirds to Mexico. The third shall not be less than 431.721. million $\mathrm{m}^{3} / \mathrm{year}$ as an average over cycles of 5 consecutive years. Two international dams, Amistad and Falcon, are used to store and manage the water for both countries and each country has its own storage account in each reservoir. The treaty cycles can expire in less than five years if the account of U.S. storage in both dams is filled with water. Before the signature of the treaty, an analysis of the six tributaries outflow was done in order to evaluate the treaty obligations. This analysis showed that Mexico will not comply very frequently with the volume of water specified for every treaty cycle; however the deficits were supposed to be small and the system expected to recover fast filling frequently the international reservoir. After 1944, records show that the treaty obligations have been delivered more frequently that expected; however deficits have been large and the system has not recover fast. In this paper we determine the expected performance of the treaty obligations from Mexico to the U.S. when the treaty was signed; evaluate the historic performance of the treaty obligations after the treaty signature; and compare both periods to determine if the performance expected at the treaty's signature met or not. Performance criteria of reliability, vulnerability and resilience are used to evaluate the treaty performance.
\end{abstract}

\section{INTRODUCTION}

It has been more than 57 years since the water division, established in the Treaty of 1944 between Mexico and the United States (US), came into force in the Rio Grande/Bravo on October $1^{\text {st }}, 1953$. Since then, 30 treaty cycles have occurred, 26 non-deficit cycles lasting 37 years and 4 deficit cycles lasting 20 years. At present, cycle 31 started in October $10^{\text {th }}$ 2010, after the US storage in both international reservoirs was filled. With all these records and data at hand; is the performance of water delivery from Mexico to the US as expected when the treaty was signed? Furthermore, was the expected performance of water delivery from Mexico to the US known when the treaty was signed? 
The aim of this paper is to establish the expected performance of water delivery from Mexico to the US when the treaty was signed and to compare this expected performance to the actual performance based on the historical records.

\section{TREATY OF 1944}

The 1944 Treaty between the US and Mexico specifies the water allocation for the Rio Grande, Colorado and Tijuana rivers. Articles 4 though 9 define the Rio Grande/Bravo water allocation for both countries. The US has ownership of: (1) all the waters reaching the Rio Grande/Bravo from the Pecos and Devil Rivers, Goodenough Spring, and Alamito, Terlingua, San Felipe and Pinto Creeks; (2) onethird of the flow reaching the Rio Grande/Bravo from six Mexican tributaries (Rio Conchos, San Diego, San Rodrigo, Escondido and Salado Rivers and Arroyo Las Vacas), provided that this third shall not be less than 431.721 million $\mathrm{m}^{3} /$ year as an average over cycles of 5 consecutive years; and (3) one half of all other flows not otherwise allotted along the Rio Grande. Mexico has ownership of: (1) all the waters reaching the Rio Grande/Bravo from the San Juan and Alamo Rivers, including the return flows from lands irrigated from these rivers; (2) two-thirds of the flow reaching the Rio Grande from the six tributaries named above; and (3) one-half of all other flows not otherwise allotted occurring along the Rio Grande/Bravo (IBWC 1944). Figure 1 shows the location of the rivers named above.

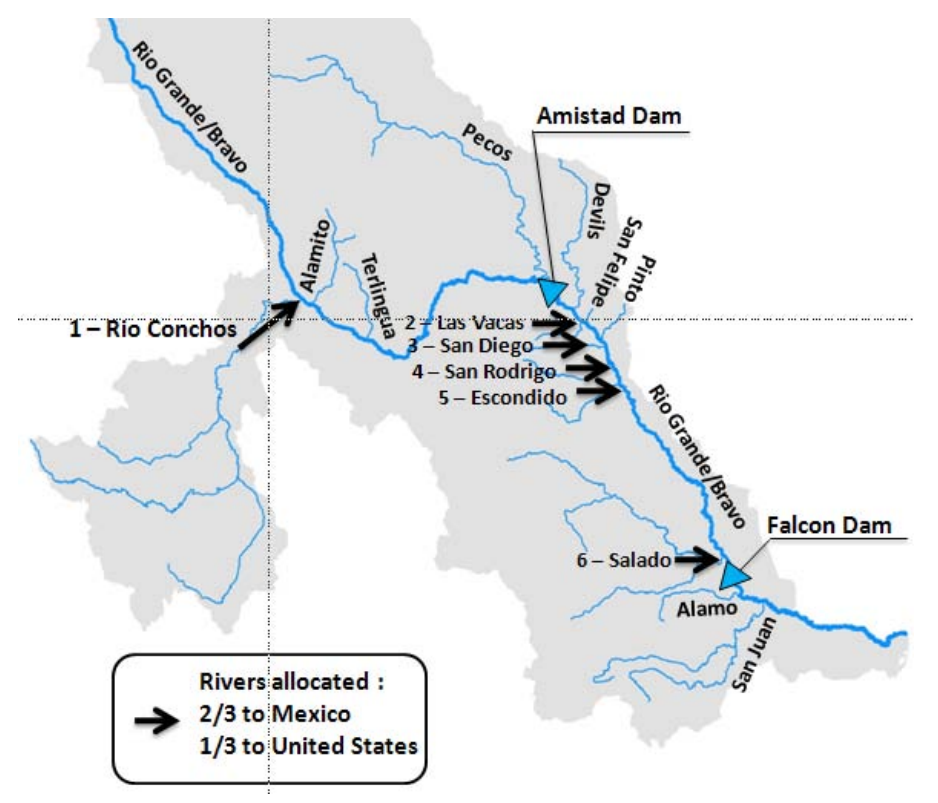

Figure 1. Rio Grande/Rio Bravo

Two international dams were built to store and manage the water for both countries, Falcon (1952) and Amistad (1968); each country has its own storage account in each reservoir. Amistad has a conservation capacity of 3,887 million $\mathrm{m}^{3}$, of which $56.2 \%$ belongs to the US and $43.8 \%$ belongs to Mexico. Falcon dam has a conservation capacity of 4,889 million $\mathrm{m}^{3}$, of which $58.6 \%$ belongs to the US and $41.1 \%$ belongs to Mexico. Treaty cycles expire in less than five years if the US storage in both dams is filled. 
The Mexican water deliveries specified in the treaty must be fulfilled from the one-third outflow of the six Mexican tributaries listed above. At the end of a 5-year cycle, the delivery from these tributaries is evaluated to determine compliance with the treaty obligations. If there is a deficit in the delivery, it must be paid in the following cycle primarily by using the one-third outflow from the six tributaries, and extraordinarily by delivering water from the Mexican portion of the tributaries listed above and/or transferring water from Mexican storage in the international dams (IBWC 1969).

\section{PRE-TREATY ANALYSIS (PRIOR TO 1944)}

Before the treaty signature and during the negotiations, several analyses were done to evaluate the feasibility of what was proposed in the treaty (Orive 1945). The technical report presented by Orive (1945) to the Mexican Chamber of Senators shows the calculations used to define the US and Mexican allotment in the Treaty, and the expected deliveries of water from Mexico to the U.S in the Rio Grande/Bravo basin. Data from this report are used to determine the expected performance of water deliveries from Mexico to the U.S. when the treaty was signed. The hydrologic period of analysis used during the negotiations was 1900 to 1942. The deliveries of water from Mexico to the U.S. will be referred as treaty obligations.

Two different cases were considered by Orive (1945) to evaluate the treaty obligations: I) before Falcon dam's construction when the system is not fully developed and 5 year treaty cycles are enforced; and II) after the dam's construction when the system is fully developed, and treaty cycles can expire earlier than 5 years. Short treaty cycles (less than 5 years) were considered when outflow from the 6 Mexican tributaries was larger than 2,000 million $\mathrm{m}^{3} /$ year.

Three performance criteria (Hashimoto et al. 1982) are used to evaluate the treaty obligations: reliability--the percent of time treaty obligations were supplied satisfactorily; resilience--the probability that the system recovers from a deficit in the next period; and vulnerability--the expected value of the deficits expressed as a percent.

Table 1 shows the reliability, resilience and vulnerability for both cases. For Case I, when the system is not fully developed, the reliability is $56 \%$, meaning $44 \%$ of the time deficits in delivery were expected; a resilience of $65 \%$ meaning 2 out 3 times the system recovers from a deficit in the next treaty cycle; and a vulnerability of $10 \%$, meaning the average deficit was expected to be only $10 \%$ of the treaty obligations. For Case II when the system is fully developed, as it is now, reliability is $42 \%$, indicating that $58 \%$ of the time deficits in delivery were expected, a resilience of $80 \%$ meaning 4 out of 5 times the system recovers from a deficit in the following treaty cycle, and vulnerability of $9 \%$, indicating the average deficit was expected to be about $9 \%$ of the treaty obligations.

In summary: (1) the system was expected to regularly experience deficits, about half of the time; (2) the recovery of the system was expected to be fast, mostly by the occurrence of wet periods that (a) compensate the small deliveries during dry years, and/or (b) fill the US capacity in the international reservoirs; and (3) it would not be possible to meet the treaty obligations all the time; however, deficits were 
expected to be small, only $10 \%$ of the treaty obligations. Besides, it was considered that these deficits would be covered without harm to water users.

Table 1. Performance Criteria Expected for the Treaty of 1944

\begin{tabular}{lcc}
\hline & $\begin{array}{c}\text { Case I } \\
\text { System Not Fully } \\
\text { Developed (\%) }\end{array}$ & $\begin{array}{c}\text { Case II } \\
\text { System Fully } \\
\text { Developed (\%) }\end{array}$ \\
\hline Reliability & 56 & 42 \\
Resilience & 65 & 80 \\
Vulnerability & 10 & 9 \\
\hline
\end{tabular}

At that time it was acknowledged water availability in the basin has high variability; in fact, this variability was considered an advantage, knowing that wet years will make up for deficits that will inevitably happen during dry years or fill the international reservoirs. In addition, the period to manage the delivery of treaty obligations was considered to be two cycles, rather than one. The rules were set so that a deficit cycle followed by a non-deficit cycle or a short cycle (due to filling international reservoirs) can be considered a successful event (Orive 1945). In conclusion, the treaty of 1944 was signed relying on high resilience and low vulnerability of the system, rather than on high reliability of the system.

\section{POST-TREATY SIGNATURE ANALYSIS (1953-2010)}

In this section the historic performance of treaty obligations are analyzed and compared with the expected performance when the treaty was signed. Both cases are evaluated, Case I when the system was not fully developed and Case II when the system is fully developed, as it is today. Data for analyzing the historic treaty obligations are derived from CONAGUA (2004) and CILA (2010).

Table 2 compares the performance criteria for Case I (1953-1968). Results show the system was in deficit less often (higher reliability) than was expected; also the system recovers faster (higher resilience); however, the average deficit was bigger than expected (higher vulnerability). Table 2 also compares performance criteria for Case II (1968-2009). Similar to Case I, the system was in deficit less often (higher reliability) than expected. In contrast, the system recovers slower (lower resilience) and once again the average deficit was bigger than expected (higher vulnerability).

On one hand, the treaty obligations were delivered successfully more often than expected (higher reliability) but on the other hand, the speed of recovery from deficits was not as fast as expected (lower resilience), and the deficits were bigger than expected (higher vulnerability). The last two results are against the original schema supported on high resilience and low vulnerability of treaty obligations. In conclusion, historical treaty deliveries have shown different performance than the 1944 Treaty signature premises: higher reliability, lower resilience and high vulnerability.

Case II represents the fully developed system as it is today. To evaluate this case, four sub-periods were identified (Table 3). The sub-period durations are different because cycle lengths vary from each other; for instance sub-period 3 is 
formed by three five year cycles (25, 26 and 27), while sub-period 1 is formed by 8 short treaty cycles (from 4 to 11) whose durations vary from a few days (such as cycle 9 from Nov. 7 to Nov. 16, 1978) to years (such as cycle 4 from Oct. 1, 1968 to Aug 21, 1972).

Table 2. Historic and Expected Performance Criteria, Case I and Case II

\begin{tabular}{lcccc}
\hline & \multicolumn{2}{c}{ Case I } & \multicolumn{2}{c}{ Case II } \\
& $\begin{array}{c}\text { Expected } \\
\text { Performance }\end{array}$ & $\begin{array}{c}\text { Historic } \\
\text { Performance }\end{array}$ & $\begin{array}{c}\text { Expected } \\
\text { Performance }\end{array}$ & $\begin{array}{c}\text { Historic } \\
\text { Performance } \\
\end{array}$ \\
& $(\%)$ & $(\%)$ & $(\%)$ & $(\%)$ \\
\hline Reliability & 56 & 67 & 42 & 63 \\
Resilience & 65 & 100 & 80 & 67 \\
Vulnerability & 10 & 27 & 9 & 30 \\
\hline
\end{tabular}

Table 3. Groups of Treaty Cycles, Case II: System Fully Developed (1969 - 2009)

\begin{tabular}{cccccccc}
\hline & \multicolumn{2}{c}{ Period } & Duration & Relia. & Resil. & Vuln. \\
Sub-period & Cycles & Beginning & Ending & (years) & (\%) & $\begin{array}{c}\text { (\%) } \\
\text { (\%) }\end{array}$ \\
\hline 1 & 4 to 11 & Oct-68 & Jun-81 & 12.7 & 100 & 100 & 0 \\
2 & 12 to 24 & Jun-81 & Sep-92 & 11.3 & 55 & 100 & 13 \\
3 & 25 to 27 & Sep-92 & Sep-07 & 15.0 & 33 & 50 & 38 \\
4 & 28 to 29 & Oct-07 & Feb-09 & 1.4 & 100 & 100 & 0 \\
\hline Whole Period & 4 to 29 & Oct-68 & Feb-09 & $\mathbf{4 0 . 4}$ & $\mathbf{6 3}$ & $\mathbf{6 7}$ & $\mathbf{3 0}$ \\
\hline Expected(<1944) & --- & -- & --- & --- & $\mathbf{4 2}$ & $\mathbf{8 0}$ & $\mathbf{9}$ \\
\hline
\end{tabular}

Figure 2a shows the reliability; for most of the cycles it was acceptable (above $42 \%$ ), except for cycles 25 to 27, when an extended and severe drought occurred in the basin (1994-2007). Following the same trend, resilience (Figure 2b) was acceptable for most of the cycles (above 80\%), except for cycles 25 to 27, when two consecutive deficit cycles occurred. Figure 2c shows the vulnerability; for this performance criteria two sub-periods, cycles 12 to 24 and 25 to 27, have a higher vulnerability than the value expected (9\%). In fact, all deficits were bigger than the expected value. Notice that for cycle 25 to 27, vulnerability is 38\% of the treaty obligations, four times larger than expected. The period of time that corresponds to cycles 25 to 27 (Oct 92 to Sep 07) is one of the worst drought periods in the basin record, slightly less severe than the record drought of the 1950's (1947-1957). The results show that under drought conditions, the system does not recover as fast as expected and the deficits are expected to be bigger than what was estimated and can be significantly large resulting in increased risk for water users and the treaty obligations.

\section{DISCUSSION}

The historic performance is the result of the combined effects of water management and the natural hydrology of the basin. Table 4 shows the average 
annual water balance before and after the treaty signature. Data for the pre and posttreaty analysis is taken from Orive (1945), Enriquez-Coyro (1976), CONAGUA (2008), Brandes (2003) and IBWC (2010).
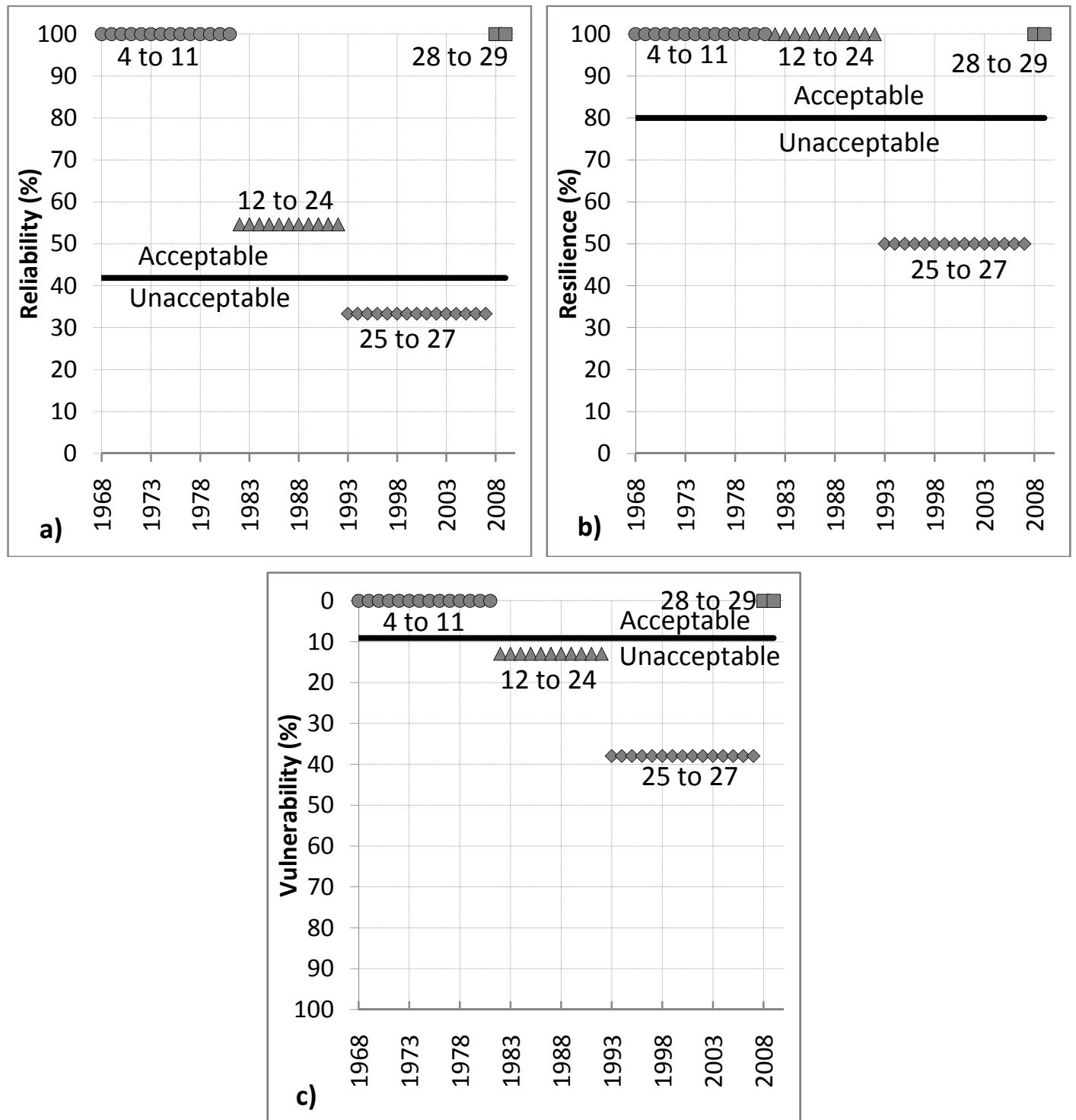

Figure 2. (a) Reliability, (b) Resilience and (c) Vulnerability by sub-period

Orive (1945) presented a pre-treaty analysis of the expected hydrology and water management in the basin (Table 4). This analysis shows that for the 6 tributaries listed in the Treaty, there is a positive balance of 1,423 million $\mathrm{m}^{3} /$ year between the naturalized flows and the consumptive use. In fact, one-third of the outflow (surplus) from the 6 tributaries was estimated to be 474 million $\mathrm{m}^{3} /$ year, slightly larger than the average annual treaty obligations (432 million $\mathrm{m}^{3} /$ year). Similarly, a positive balance of 2,420 million $\mathrm{m}^{3} /$ year was estimated for all the inflows of Mexican tributaries to the Rio Grande/Bravo and the gains along the main stream. Finally, a positive balance of 644 million $\mathrm{m}^{3} /$ year was estimated between the 
available Mexican water in the Rio Grande/Bravo mainstream and the consumptive use along the river. For the US, a positive balance of 2,533 million $\mathrm{m}^{3} /$ year was estimated for all the inflows of US tributaries, the gains along the main stem and the one-third of the 6 Mexican tributaries. Similar to Mexico, a positive balance of 548 million $\mathrm{m}^{3} /$ year was estimated between the available US water in the main stem and the consumptive use along the river. The remaining water, 644 (Mexico) and 584 (US) million $\mathrm{m}^{3} /$ year, was for conveyance losses, evaporation, mitigation of droughts, and drainage, among others.

For the post-treaty analysis (1950-2004) evaporation losses in reservoirs are considered in the water balance. For the 6 tributaries, there is a positive balance of 1,364 million $\mathrm{m}^{3} /$ year; one-third of the Mexican outflow (455 million $\mathrm{m}^{3} / \mathrm{year}$ ) is slightly larger than the average annual treaty obligations. Notice that the annual naturalized flow $\left(3,506\right.$ million $\left.\mathrm{m}^{3}\right)$ is larger than expected in the post-treaty analysis (3,388 million $\left.\mathrm{m}^{3}\right)$, however, there are larger consumptive uses and evaporation. A positive balance of 1,560 million $\mathrm{m}^{3}$ /year has been estimated for all the inflows of Mexican tributaries and the gains along the main stem. Finally, a small negative balance of 16 million $\mathrm{m}^{3} /$ year is estimated between the available Mexican water and the consumptive use along the main stem of the river.

For the US, a positive balance of 1,444 million $\mathrm{m}^{3} /$ year is estimated for the inflows of US tributaries, the gains along the main stem and one-third of the 6 Mexican tributaries. Similar to Mexico, the balance between the available US water and the consumptive use along the river is small, about 2 million $\mathrm{m}^{3} /$ year.

In the whole basin, evaporation losses in reservoirs account for $23 \%(1,702$ million $\left.\mathrm{m}^{3}\right)$ of the mean annual naturalized flows $\left(7,343\right.$ million $\left.\mathrm{m}^{3}\right)$ in the basin, which is a significant amount of water.

The slightly negative balance of water along the Rio Grande/Bravo main stem shows the high state of stress of the system. Figure 3 shows the historical water consumption in the basin. For all Mexican tributaries (Figure 3.c), there was a linear increase in consumption from 1950 to 1994. For treaty cycles 12 to 24 (1981-1992) the water consumption was already above the expected consumption; this could be the reason why the vulnerability was larger than expected. Furthermore, in the first two years of cycles 25 to 27 (1993-2007) consumption was above the expected amount; water resources in the tributaries were exhausted at the beginning of drought (1994-2007). Likewise, Mexican consumption along the Rio Grande/Bravo (Figure 3.a) increased linearly from 1950 to 1994. During cycles 25 to 27, Mexican water supply was reduced drastically because of the extended drought, the exhausted water resources in the tributaries and the payment of treaty obligations to the US.

In contrast, US consumption along the Rio Grande/Bravo (Figure 3.b) has been close to the mean value, except for 1989 when more than 2,000 million $\mathrm{m}^{3}$ were consumed. The previous analysis exemplifies the problem of over-consumption of water, mostly in Mexico.

\section{CONCLUSIONS}

This paper presents the expected and historic performance of treaty obligations. The treaty was signed relying on low deficits (low vulnerability) and fast recovery from deficit periods (high resilience) rather than always delivering the treaty 
obligations (low reliability). The historic deliveries show an opposite performance, the treaty obligations were delivered more frequently (higher reliability); however, the deficits were larger (high vulnerability) and the system did not recovered as fast as expected (low resilience).

The water balance analysis shows that one of the causes of this opposite performance might be the over-consumption of water, mostly in Mexico. Also, extended droughts played an important factor, increasing the scarcity of water resources and increasing the tension between the basin countries.

In 2004, water rights in Mexico and the US were estimated to be 4,532 and 2,129 million $\mathrm{m}^{3} /$ year, respectively. Recently, several policies have been implemented to reduce the water rights in the basin, such as buy-backs, infrastructure improvements and water rights reduction. In 2008, water rights in Mexico and the US have been reduced to 4,401 and 1,953 million $\mathrm{m}^{3} /$ year, respectively; however, this is still above the historic values expected in the treaty, showing the over-allocation of water rights in the basin. Furthermore, the analysis does not consider water for the environment; probably water rights for human consumption could be less than the historic value.

\section{ACKNOWLEDGEMENTS}

Special acknowledgements are given to the National Council of Science and Technology of Mexico (CONACYT), Robert B. Gilbert (UT Austin), Jose Alfredo Galindo Sosa (CONAGUA), Gilbert Anaya (IBWC), Ramiro Lujan Godinez (CILA), Roberto Salmon Castelo (CILA), and Carlos Rubinstein (TCEQ).

\section{REFERENCES}

Brandes Company, R.J. (2003) "Water Availability Modeling for the Río Grande Basin: Naturalized Streamflow Data. Final Report.” Texas Commission on Environmental Quality, Austin, TX.

CILA - Comisión Internacional de Límites y Aguas (2010). "Informe sobre las asignaciones de agua a Estados Unidos del Rio Bravo.”Contabilidad del Bravo $<$ http://www.sre.gob.mx/cila/> (Dec. 12, 2010).

CONAGUA - Comisión Nacional del Agua (2004). "Estadísticas del Agua en México.” Edición 2004. México D.F.

CONAGUA - Comisión Nacional del Agua. (2008). "Acuerdo por el que se da a conocer el resultado de los estudios de disponibilidad media anual de las aguas superficiales en la cuenca del Rio Bravo.” Diario Oficial de la Federación. 29 de Septiembre de 2008.

Enriquez-Coyro, E., (1976). "El Tratado entre México y los Estados Unidos de América sobre Ríos Internacionales.” Facultad de Ciencias Políticas y Sociales. Universidad Nacional Autónoma de México.

Hashimoto, T., Stedinger, J.R., and Loucks, D.P. (1982). "Reliability, resiliency and vulnerability criteria for water resource system performance evaluation.” Water Resources Research 18 (1), 14-20.

International Boundary and Water Commission (IBWC). (1944). "Treaty between the United States and Mexico.” Utilization of waters of the Colorado and Tijuana Rivers and of the Rio Grande, IBWC, Washington, D.C. 
International Boundary and Water Commission (IBWC). (1969). "Minute 234:" Waters of the Rio Grande allotted to the United States from the Conchos, San Diego, San Rodrigo, Escondido and Salado rivers and the Las Vacas Arroyo, IBWC, Ciudad Juarez, Chihuahua, Dec. 2, 1969.

IBWC - International Boundary and Water Commission (2010). "Rio Grande Historical Mean Daily Discharge "Data." <http://www.ibwc.state.gov/Water_Data/histflo1.htm> (Dec. 31, 2010).

Orive Alba, Adolfo (1945). "Informe técnico sobre el tratado internacional de aguas" Comisión Nacional de Irrigación. México D.F., Sep. 1945.
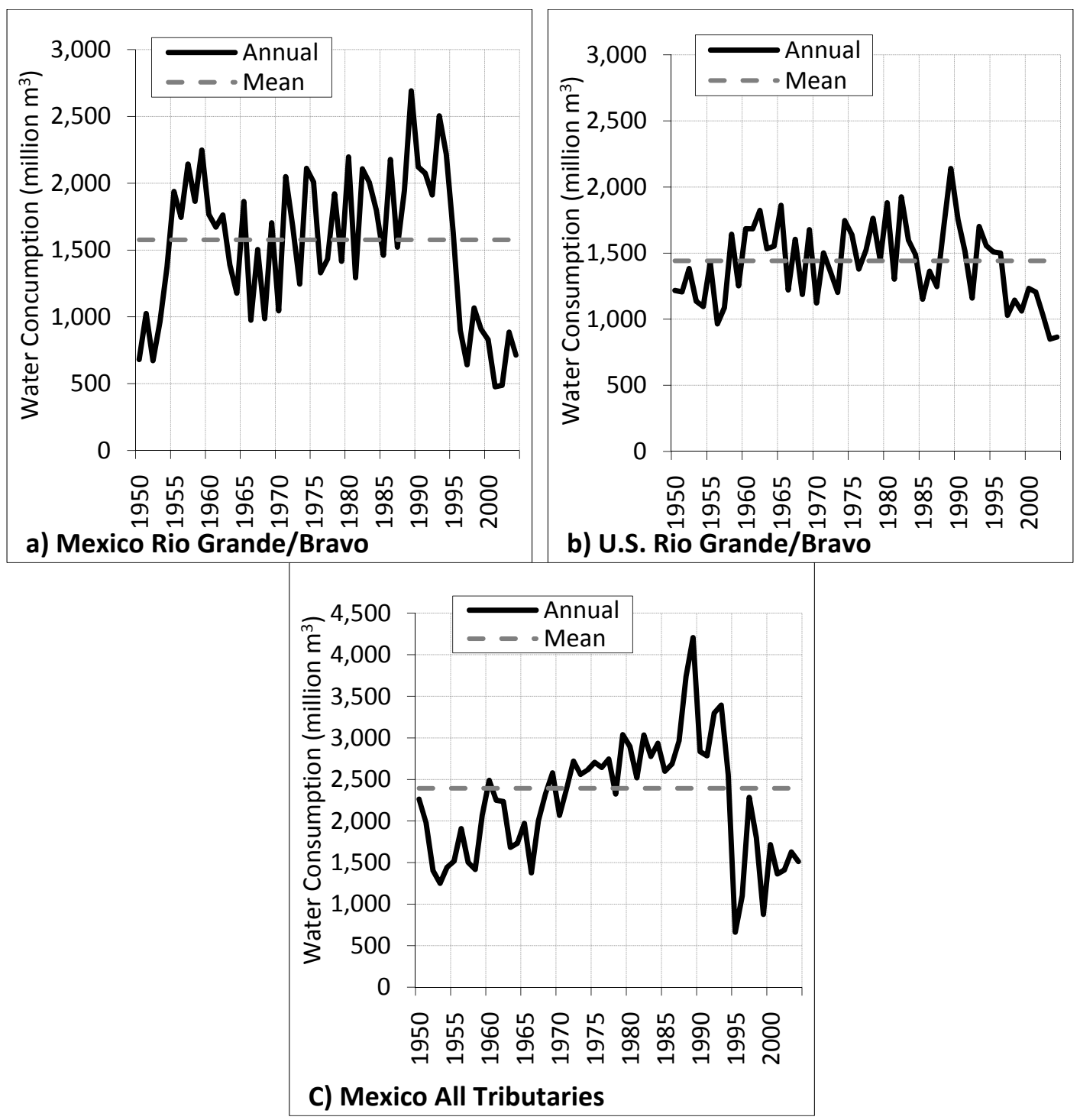

Figure 3. Water Consumption 
Table 4. Average annual water balance, Pre and Post treaty Analysis

Orive (pre-1944)

Historic (1950-2004)

\begin{tabular}{|c|c|c|c|c|c|c|c|}
\hline & $\begin{array}{l}\text { Nat. Flows } \\
\left(\text { million } \mathrm{m}^{3}\right)\end{array}$ & $\begin{array}{c}\text { Consump. Use } \\
\left(\text { million } \mathrm{m}^{3}\right)\end{array}$ & $\begin{array}{c}\text { Surplus } \\
\left(\text { million } \mathrm{m}^{3}\right)\end{array}$ & $\begin{array}{l}\text { Nat. Flows } \\
\left(\text { million } \mathrm{m}^{3}\right)\end{array}$ & $\begin{array}{l}\text { Consump. Use } \\
\left(\text { million } \mathrm{m}^{3} \text { ) }\right.\end{array}$ & $\begin{array}{l}\text { Evaporation } \\
\left(\text { million } \mathrm{m}^{3}\right)\end{array}$ & $\begin{array}{l}\text { Surplus/Deficit } \\
\left(\text { million } \mathrm{m}^{3}\right) \\
\end{array}$ \\
\hline MEXICO & 5,338 & 4,694 & 644 & 5,063 & 3,968 & 1,112 & -16 \\
\hline \multicolumn{8}{|l|}{6 Tributaries } \\
\hline 1 - Rio Conchos & 2,045 & 1,275 & 770 & 2,255 & 1,267 & 281 & 707 \\
\hline 2- LV, SD, SR and ES ${ }^{1}$ & 418 & 128 & 290 & 410 & 49 & 5 & 356 \\
\hline 3.- Salado & 925 & 562 & 363 & 841 & 383 & 157 & 301 \\
\hline Total 6 Tributaries & 3,388 & 1,965 & 1,423 & 3,506 & 1,699 & 443 & 1,364 \\
\hline Surplus US: $1 / 3$ of 6 Tributaries & & & 474 & & & & 455 \\
\hline \multicolumn{8}{|l|}{ Tributaries \& Gains } \\
\hline 1- 6 Tributaries & 2,914 & 1,965 & 949 & 3,061 & 1,699 & 443 & 909 \\
\hline II - Alamo and San Juan & 1,557 & 953 & 604 & 1,236 & 693 & 339 & 204 \\
\hline III - Gains along Rio Grande/Bravo & 867 & --- & 867 & 776 & --- & 330 & 446 \\
\hline Total Tributaries \& Gains (I + II + III) & 5,338 & 2,918 & 2,420 & 5,063 & 2,392 & 1,112 & 1,560 \\
\hline \multicolumn{8}{|l|}{ Along the Rio Grande $(\mathrm{MX})$} \\
\hline UNITED STATES & 3,521 & 2,937 & 584 & 2,280 & 1,688 & 590 & 2 \\
\hline I- 6 Tributaries & 474 & $-\overline{---}$ & 474 & 445 & --- & --- & 455 \\
\hline II - PE, DE, GE, AL, TE, SF and $\mathrm{PI}^{2}$ & 2,180 & 988 & 1,192 & 1,049 & 246 & 76 & 727 \\
\hline III - Gains along Rio Grande/Bravo & 867 & 0 & 867 & 776 & 0 & 514 & 262 \\
\hline Total Tributaries \& Gains (I + II + III) & 3,521 & 988 & 2,533 & 2,280 & 246 & 590 & 1,444 \\
\hline \multicolumn{8}{|l|}{ Along the Rio Grande (US) } \\
\hline Projects Along Rio Grande/Bravo & 2,533 & 1,949 & 584 & 1,444 & 1,442 & --- & 2 \\
\hline
\end{tabular}

${ }^{1}$ Las Vacas, San Diego, San Rodrigo and Escondido

${ }^{2}$ Pecos, Devils, Goodenough, Alamito, Terlingua, San Felipe and Pinto 